\title{
Kenneth Hagen
}

\section{Hebrews}

Commenting from

Erasmus to Bèze

$1516-1598$

1981. VIII, 125 Seiten. (Beiträge zur Geschichte der Biblischen Exegese 23). ISBN 3-16-143341-6 Kart. DM 59.-

Among the epistles, the one to the Hebrews was most controversial. The authorship question alone, after Erasmus (1516), lifted the discussion to a more textual and historical level, and posed severe theological problems. Hebrews raised questions about OT interpretation, law, gospel, Christ, priesthood, sacrifice, faith, works.

The focus is on the introduction in printed commentaries from Erasmus to Calvin, Politus to Bèze. After Calvin, introductions do more than cover the content of the epistle. They are more historical (occasio), literary (genus), methodological (loci) and linguistic (Hebraeos). After a translation of the introduction, an analysis is given in the light of medieval and (earlier) 16th century exegesis of Hebrews.

A bibliographic contribution to 16th century exegetica is attempted. Considerable effort was given to identify every edition of a Hebrews commentary to Bèze's 5 th.

One advantage of working on exegetica is that the text (Hebrews) provided some control. In other words, this study offers a fairly constant and focused view of a near century of work on sacred matters.

\section{J.C.B.Mohr (Paul Siebeck) Tübingen}




\section{Marcel Simon}

\section{Le Christianisme antique et son contexte religieux. Scripta Varia}

In zwei Bänden. 1981. Bd. I: XX, 370 Seiten. Mit 4 Tafeln. Bd. II: VI, Seiten 371-852. Mit 2Tafeln. (Wissenschaftliche Untersuchungen zum Neuen Testament 23). ISBN 3-16-143802-7. Beide Bände zusammen Ln. DM 245.-

Diese Sammlung enthält 47, zwischen 1933 und 1979 in verschiedenen Zeitschriften und Festschriften erschienene religionswissenschaftliche Aufsätze. Die meisten sind in französischer, einige in englischer Sprache verfaßt.

Den Hauptgegenstand dieser Auswahl bildet das Christentum der vier ersten Jahrhunderte. Einige Aufsätze behandeln Fragen der christlichen Archäologie, andere befassen sich mit methodologischen Problemen. Doch die große Mehrzahl weist einen ausgeprägten historischen Charakter auf. Verschiedene Richtungen im Leben der Alten Kirche sowie des Judentums und des Heidentums werden erörtert. Der Verfasser nimmt Stellung zur religionsgeschichtlichen Schule. Ohne den Ansichten dieser Schule beizupflichten, bemüht er sich dennoch, das Christentum von seiner geistigen Umwelt aus zu beleuchten. Einige Aufsätze sind dem Mithraskult gewidmet. Besondere Aufmerksamkeit wird jedoch dem Judentum und seinem Verhältnis zum Christentum zuteil. Wechselseitige Einflüsse zwischen der Alten Kirche und ihrer Umwelt werden erforscht. Die Einleitung des Buches bringt die fachlichen Grundanschauungen des Verfassers zum Ausdruck.

\section{J.C.B.Mohr (Paul Siebeck) Tübingen}




\title{
NEW TESTAMENT STUDIES
}

\author{
PUBLISHED QUARTERLY UNDER \\ THE AUSPICES OF \\ VOL. XXVII \\ I 98 I \\ EDITED BY \\ R. MCL. WILSON \\ ASSOCIATE EDITOR \\ M. E. THRALL
}

AN INTERNATIONAL JOURNAL

STUDIORUM NOVI TESTAMENTI SOCIETAS

CAMBRIDGE UNIVERSITY PRESS

CAMBRIDGE

LONDON NEW YORK NEW ROCHELLE

MELBOURNE SYDNEY

I $98 \mathrm{I}$ 
Published by the Press Syndicate of the University of Cambridge The Pitt Building, Trumpington Street, Cambridge CB2 I RP

32 East $57_{\text {th }}$ Street, New York, NY 10022, USA

(C) Cambridge University Press, 1981

Printed in Great Britain at the University Press, Cambridge 


\section{CONTENTS}

Professor R. A. Culpepper (Louisville, U.S.A.) The Pivot of John's Prologue page 1

Professor R. A. Horsley (Boston, U.S.A.) Gnosis in Corinth: I Corinthians 8.1-6

Dr W. L. Richards (Angwin, U.S.A.) An Examination of the Claremont Profile Method in the Gospel of Luke

Professor Dr H. Weder (Zurich, Switzerland) Zum Problem Einer Christlichen Exegese

Professor Dr D. Lührmann (Bielefeld, Germany) Neutestamentliche Haustafeln und antike ökonomie

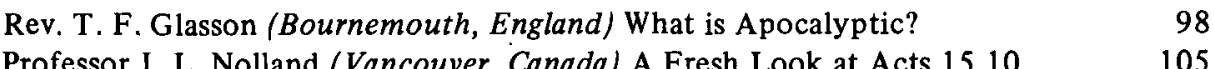

Dr B. D. Chilton (Sheffield, England) The Transfiguration: Dominical Assurance and Apostolic Vision

Rev. J. I. Miller (Suffolk, England) A Fresh Look at 1 Corinthians 6.16f.

Rev. G. E. Okeke (Nigeria, Africa) I Thess. ii. 13-16: The Fate of the Unbelieving Jews

Rev. C. L. Mearns (Ripon, England) Early Eschatological Development in Paul: the Evidence of I and II Thess.

Dr U. B. Müller (Kiel, Germany) Zur Rezeption Gesetzeskritischer Jesusüberlieferung im frühen Christentum

Dr Christian Wolff (Berlin, Germany) Die Gemeinde des Christus in der Apokalypse des Johannes

Dr N. H. Young (New South Wales, Australia) The Gospel according to Hebrews 9

Dr Margaret Pamment (Bristol, England) The Kingdom of Heaven According to the First Gospel

Dr R. T. France (Cambridge, England) The Formula Quotations of Matthew 2 and the Problem of Communication

Rev. David Seccombe (Cambridge, England) Luke and Isaiah

Dr. Ahmad Shafaat (Jeddah, Saudi Arabia) Geber of the Qumran Scrolls and the Spirit Paraclete of the Gospel of John

Pastor Gunther Schwarz (Diepholz, Germany) Zum Vokabular von Matthäus XXV 1-12

Professor Thomas R. W. Longstaff (Waterville, Maine, U.S.A.) The Women at the Tomb: Matthew 28:1 Re-examined

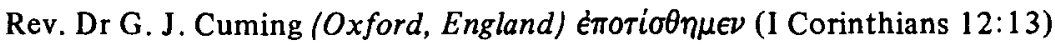

Professor Barnabas Lindars (Manchester, England) John and the Synoptic Gospels: A Test Case

Professor Morna D. Hooker (Cambridge, England) Beyond the Things that are Written? St. Paul's Use of Scripture

Professor Otto Böcher (Mainz-Drais, Germany) Johanneisches in der Apokalypse des Johannes

Dr Richard Bauckham (Manchester, England) The Worship of Jesus in Apocalyptic Christianity

Dr M. D. Goulder (Birmingham, England) The Apocalypse as an Annual Cycle of Prophecies 


\section{CONTENTS}

Professor Petr Pokorný (Prague, Czechoslovakia) Christologie et Baptême à l'Epoque du Christianisme Primitif

Professor G. Johnston (Montreal, Canada) Christ as Archegos

Mr Howard M. Jackson (Claremont, U.S.A.) Geradamas, the Celestial Stranger

Mr Craig A. Evans (Ontario, Canada) On the Prologue and the Trimorphic Protennoia

Monsieur A. Delclaux (Paris, France) Deux Témoignages de Papias sur la Composition de Marc?

Professor S. Gero (Tübingen, Germany) The Gates or the Bars of Hades? A Note on Matthew 16.18

Professor X. Léon-Dufour (Paris, France) Towards a Symbolic Reading of the Fourth Gospel

Professor D. Lührmann (Bielefeld, Germany) Markus 14.55-64: Christologie und Zerstörung des Tempels im Markusevangelium

Professor John Reumann (Philadelphia, U.S.A.) 'The Problem of the Lord's Supper' as Matrix for Albert Schweitzer's 'Quest of the Historical Jesus'

Professor William Klassen (Winnipeg, Canada) 'A Child of Peace' (Luke 10.6) in First Century Context

Rev. J. W. Wenham (Oxford, England) Synoptic Independence and the Origin of Luke's Travel Narrative

Professor Kikuo Matsunaga (Tokyo, Japan) Is John's Gospel AntiSacramental? - A New Solution in the Light of the Evangelist's Milieu

Dr John Painter (Bundoora, Australia) The Farewell Discourses and the History of Johannine Christianity

Rev. F. G. Downing (Manchester, England) Ethical Pagan Theism and the Speeches in Acts

Abbé Edouard Cothenet (Bourges, France) Le réalisme de l'espérance chrétienne selon 1 Pierre

Professor T. E. Pollard (Dunedin, New Zealand) Colossians 1.12--20: A Reconsideration

Dr Karel Hanhart (Brussels, Belgium) The Four Beasts of Daniel's Vision in the Night in the Light of Rev. 13.2

Professor Dr H. W. Bartsch (Lich, Germany) Ein neuer Textus Receptus für das griechische Neue Testament?

Dr Ben Witherington (Coleridge, U.S.A.) Rite and Rights for Women Galatians 3.28

Herr Folker Siegert (Tübingen, Germany) Unbeachtete Papiaszitate bei armenischen Schriftstellern

Dr B. E. Thiering (Sydney, Australia) Qumran Initiation and New Testament Baptism

Professor T. Baarda (Amsterdam, Holland) Another Treatise of Aphrahat the Persian Sage in Ethiopic Translation

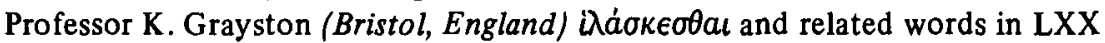

Dr F. J. Moloney (Oakleigh, Vic., A ustralia) The Re-interpretation of Psalm VIII and the Son of Man Debate

Professor M. Gourgues (Ottawa, Canada) A propos du Symbolisme christologique et baptismal de Marc 16.5

Dr P. W. Barnett (North Ryde, Australia) The Jewish Sign Prophets A.D. 40-70. Their Intentions and Origin

Professor J. G. Gager (Princeton, U.S.A.) Some Notes on Paul's Conversion 


\section{CONTENTS}

Rabbi D. Cohn-Sherbok (Canterbury, England) A Jewish Note on TO IIOTHPION TH $\Sigma$ ET $\Lambda$ OГIA $\Sigma$

Studiorum Novi Testamenti Societas

Report of Toronto Meeting

Officers and Committee Members

416

Membership List

417 
C) Cambridge University Press 1981

PRINTED IN GREAT BRITAIN AT THE UNIVERSITY PRESS, CAMBRIDGB https://doi.org/10.1017/S0028688500007074 Published online by Cambridge University Press 